\title{
COMMUNICATION
}

\section{FAILURE OF IMIDACLOPRID AND THIACLOPRID TO CONTROL THE GUAVA-PSYLLID, Triozoida limbata (ENDERLEIN) (HEMIPTERA: PSYLLIDAE)}

\author{
Insucesso de imidacloprid e thiacloprid no controle do psilídeo-da-goiabeira, \\ Triozoida limbata (Enderlein) (Hemiptera: Psyllidae)
}

\author{
José Oscar Gomes de Lima1, Geraldo do Amaral Gravina²
}

\begin{abstract}
The guava-psyllid, Triozoida limbata (Enderlein), is a severe pest of guava orchards, reducing fruit production. This communication shows the results of an experiment aimed to test nicotinoid insecticides for controlling the guava-psyllid at a highdensity level of infestation. Unsatisfactory control of this pest was achieved with imidacloprid AL $100 \mathrm{~g} / \mathrm{L}$, at 5,10 or $20 \mathrm{~mL}$ sprayed once onto the guava stem; with imidacloprid SC $200 \mathrm{~g} / \mathrm{L}$, at $0.6 \mathrm{~mL}$ in $2 \mathrm{~L}$ of water/tree and with thiacloprid SC $480 \mathrm{~g} / \mathrm{L}$, at $0.2 \mathrm{~mL}$ in $2 \mathrm{~L}$ of water/tree, both sprayed twice (15 day interval) on the guava foliage. Possible causes of the failure are discussed in relation to several factors, since previous research showed satisfactory control of the guava-psyllid with these insecticides.
\end{abstract}

Index terms: Guava, nicotinoid insecticides, stem application, foliage spraying.

\section{RESUMO}

O psilídeo-da-goiabeira, Triozoida limbata (Enderlein), é uma praga severa que compromete a produtividade da goiabeira. Esta comunicação apresenta os resultados de um experimento em que objetivou-se testar inseticidas nicotinóides para o controle do psilídeo-da-goiabeira, em elevada densidade populacional. Não se conseguiu controle satisfatório com imidacloprid AL $100 \mathrm{~g} / \mathrm{L}$, pulverizado uma única vez na base do tronco da goiabeira a 5,10 ou $20 \mathrm{~mL} /$ planta; com imidacloprid SC $200 \mathrm{~g} / \mathrm{L}$, usando-se $0,6 \mathrm{~mL}$ em $2 \mathrm{~L}$ de água/planta e com o thiacloprid SC $480 \mathrm{~g} / \mathrm{L}$, usando-se $0,2 \mathrm{~mL}$ em $2 \mathrm{~L}$ de água/planta, ambos pulverizados duas vezes (15 dias de intervalo) na folhagem. Como a eficácia desses produtos havia sido constatada anteriormente, as possíveis causas da atual falha de controle são discutidas em relação a vários fatores.

Termos para indexação: Goiaba, inseticidas nicotinóides, aplicação via tronco, pulverização da folhagem.

(Received in july 12, 2007 and approved in july 31, 2008)

Triozoida limbata (Enderlein), commonly known as guava-psyllid in Brazil, is an occasional pest of guava. However, in areas where pruning management is frequently carried out to obtain year-round production, this insect may become a key pest, once it attacks only immature leaves (NAKANO \& SILVEIRA NETO, 1968). The damage inflicted to guava leaves by the guava-psyllid may be aggravated in orchards where frequent pruning is coupled with improper use of insecticides. Inappropriate use of insecticides could be related to the lack of insecticides registered for controlling the guava-psyllid, since there is just one formulation of the neonicotinoid imidacloprid that has been recently registered (AGROFIT, 2008). Neonicotinoids, which are remarkably effective insecticides against sucking insect pests, and relatively less toxic to vertebrates (TOMIZAWA \& CASIDA, 2005), have been shown to effectively control the guava-psyllid (BARBOSA et al., 2001b, 2003). Furthermore, safety of natural enemies and an extended period of activity are assured with neonicotinoids like imidacloprid, specially when formulated for stem application (BARBOSA et al., 2001a). Apart from the neonicodinoids imidacloprid, thiacloprid, and thiamethoxan; pyrethroids such as betacyfluthrin and lambdacyalothrin have also been shown to be effective against the guava-psyllid (BARBOSA et al., 1999, 2001b, 2003). An economic threshold level of $30 \%$ of branches infested has been estimated for the guava-psyllid, but the efficacy of insecticides applied at such high-density infestation is unknown, except for thiamethoxan that was ineffective (BARBOSA et al., 2003). Thus, this study was

'Engenheiro Agrônomo, PhD em Entomologia - Centro de Ciências e Tecnologias Agropecuárias/CCTA, Laboratório de Entomologia e Fitopatologia/LEF _ Universidade Estadual do Norte Fluminense Darcy Ribeiro /UENF - Av. Alberto Lamego, 2000, Parque Califórnia - 28013-602 - Campos dos Goytacazes,RJ - joscar@uenf.br

${ }^{2}$ Engenheiro Agrônomo, D.Sc. em Fitotecnia - Centro de Ciências e Tecnologias Agropecuárias/CCTA, Laboratório de Engenharia Agrícola/LEAG Universidade Estadual do Norte Fluminense Darcy Ribeiro/UENF - Av. Alberto Lamego, 2000, Parque Califórnia - 28013-602 - Campos dos Goytacazes,RJ - gravina@uenf.br 
carried out to evaluate the efficacy of imidacloprid sprayed onto the guava stem or foliage and thiacloprid sprayed onto the guava foliage for controlling the guava-psyllid population at a high-density level of infestation.

The study was carried out in a five years old guava orchard planted $(6 \times 6 \mathrm{~m})$ in an experimental area of the Universidade Estadual do Norte Fluminense Darcy Ribeiro (UENF) at Itaocara, Rio de Janeiro State, Brazil. The formulation $\mathrm{AL}$ of imidacloprid (100 g/L) was applied undiluted with a hand sprayer (1 L capacity) onto the base of the guava stem at 5,10 or $20 \mathrm{~mL} / \mathrm{stem}$. The formulation $\mathrm{SC}$ of imidacloprid $(200 \mathrm{~g} / \mathrm{L})$ was sprayed once onto the foliage of the guava tree at $0.6 \mathrm{~m} \mathrm{~L}$ in $2 \mathrm{~L}$ of water/tree. The formulation SC of thiacloprid $(480 \mathrm{~g} / \mathrm{L})$ was also sprayed onto the foliage at $0.2 \mathrm{~mL}$ in $2 \mathrm{~L}$ of water/tree. The insecticides sprayed onto the foliage were applied twice (15 day interval) by using a motorized sprayer calibrated to deliver two liters of the insecticide mixture (water + insecticide) per tree.

Prior to the insecticide application, 20 guava branches were chosen and three to four pairs of leaves of the guava cultivars showing no symptoms of attack by the guava-psyllid were marked at their extremities. The number of marked leaves attacked by the guava-psyllid (independently of the intensity of the attack per leaf) was evaluated two times: 15 days after the first application and 13 days after the second foliage application for, at least, 10 branches per tree. This system of evaluation was adopted due to the high-density of the guava-psyllid infestation and because the insect attacks only the immature leaves (NAKANO \& SILVEIRA NETO, 1968).

The experiment was a completely randomized block design with four replicates for each of the six treatments (imidacloprid AL at 3 rates, imidacloprid SC, thiacloprid SC and control). Each replicate corresponded to one of the following guava cultivars: Paluma, Rica, Campos (unrecognized origin) and a fourth cultivar much like Paluma (here named Paluma B). The experimental unit consisted of the number of leaves at the tip of the marked branches (10 to 20 branches per tree). Using SAEG software developed by Fundação Arthur Bernardes (FUNARBE) at Universidade Federal de Viçosa (Viçosa, MG, Brazil) we performed the data analysis. Before performing ANOVA, the data were submitted to Lilliefors test for normal distribution, and Cochran and Bartlett test for homogeneity of variances. The means were separated by the Duncan multiple range test $(\mathrm{P}<0.05 \%)$.

The tests carried out for normal distribution and homogeneity of variances indicated that there was no need for data transformation $(\mathrm{P}<0.05)$. After 15 days (first evaluation) and even 13 days after the second application of the insecticides (second evaluation), none of the insecticides protected the guavas leaves satisfactorily against the guava-psyllid (Table 1). The percentage of attacked leaves on plants protected by foliage application of imidacloprid was significantly different from percentage of attacked leaves on control plants at the first evaluation. However, imidacloprid efficacy in this case was low (38,7\% more infested leaves on the control plants). At the second evaluation there was no significant difference in percentage of leaves attacked among all treatments, including control (Table 1). At that time, the percentage of leaves attacked increased on plants of all the treatments. The mean percentage of attacked leaves was 30.8 and 41.3 at the first and second evaluation, respectively, when pooling the data of all treatments. This difference was significant $(\mathrm{P}<0.05)$. Data were not taken after the second evaluation due to incessant rain that prevented further attack of the guava-psyllid to the immature leaves.

From the results, it may be perceived that insecticide efficacy was disappointing, since comparative dosages of either stem or weekly foliage application of imidacloprid and weekly foliage application of thiacloprid reduced satisfactorily the guava-psyllid infestation in other studies (BARBOSA et al., 1999, 2001b). However, Barbosa et al. (2001b) found that foliage applications of imidacloprid and thiacloprid quickly and efficiently prevented the guava-psyllid attack on the immature leaves; efficacy of stem application of imidacloprid increased over time, presenting acceptable efficacy $(>80$ $\%$ less branches attacked than branches attacked on the control plants) only 35 days after its application. In citrus, imidacloprid peak mean titers took 6 to 8 weeks after application (CASTLE et al., 2005). If this holds true for guava, we may infer that stem application of imidacloprid may be used only as a preventive measure for the guavapsyllid control, that is, before or at the beginning of the infestation.

Comparatively to the previous work, in the present study the inefficiency of the two foliage applications of imidacloprid and thiacloprid may be related to the different interval of application and the high-density of the guavapsyllid infestation at the time of their first application (> 50 $\%$ of the guava branches infested). In this context, another nicotinoid, thiamethoxan $250 \mathrm{WG}(0.02 \%)$, failed to control the guava-psyllid when the foliage spraying was initiated at the infestation level of 20 or $30 \%$ of branches attacked (BARBOSA et al., 2003). 
Table 1 - Number examined and percentage of guava leaves attacked by T. limbata after insecticide application.

\begin{tabular}{|c|c|c|c|c|}
\hline \multirow[b]{2}{*}{ Treatments $^{1}$} & \multicolumn{2}{|c|}{15 days after $1^{\text {st }}$ application ${ }^{2,3}$} & \multicolumn{2}{|c|}{13 days after $2^{\text {nd }}$ application $^{2,3}$} \\
\hline & $\begin{array}{c}\text { Number of } \\
\text { leaves examined }\end{array}$ & $\begin{array}{c}\% \text { of leaves } \\
\text { attacked }\end{array}$ & $\begin{array}{c}\text { Number of } \\
\text { leaves examined }\end{array}$ & $\begin{array}{c}\% \text { of leaves } \\
\text { attacked }\end{array}$ \\
\hline $\begin{array}{l}\text { Imidacloprid AL } 100 \mathrm{~g} / \mathrm{L} \\
\text { at } 5 \mathrm{~mL} / \mathrm{stem}\end{array}$ & 82.0 & $33.1 \mathrm{ab}$ & 109.3 & $41.7 \mathrm{a}$ \\
\hline $\begin{array}{l}\text { Imidacloprid AL } 100 \mathrm{~g} / \mathrm{L} \\
\text { at } 10 \mathrm{~mL} / \mathrm{stem}\end{array}$ & 67.0 & $35.5 \mathrm{a}$ & 89.3 & $40.4 \mathrm{a}$ \\
\hline $\begin{array}{l}\text { Imidacloprid AL } 100 \mathrm{~g} / \mathrm{L} \\
\text { at } 20 \mathrm{~mL} / \mathrm{stem}\end{array}$ & 76.3 & $26.3 \mathrm{ab}$ & 105.0 & $39.8 \mathrm{a}$ \\
\hline $\begin{array}{c}\text { Imidacloprid SC } 200 \mathrm{~g} / \mathrm{L} \\
\text { at } 0.6 \mathrm{~mL} \text { in } 2 \mathrm{~L} \text { of water/tree }\end{array}$ & 78.8 & $22.3 \mathrm{~b}$ & 109.8 & $35.6 \mathrm{a}$ \\
\hline $\begin{array}{l}\text { Thiacloprid SC } 480 \mathrm{~g} / \mathrm{L} \\
\text { at } 0.2 \mathrm{~mL} \text { in } 2 \mathrm{~L} \text { of water/tree }\end{array}$ & 69.5 & $31.0 \mathrm{ab}$ & 101.3 & $42.0 \mathrm{a}$ \\
\hline Control & 70.0 & $36.4 \mathrm{a}$ & 105.5 & $48.3 \mathrm{a}$ \\
\hline
\end{tabular}

${ }^{1}$ Insecticides were sprayed once onto the stem or twice onto the foliage with 15 days of interval

${ }^{2}$ Means of four replicates

${ }^{3}$ Means within a column followed by the same letter are not significantly different $(\mathrm{P}<0.05$; Duncan Multiple Range Test).

Rainfall might have contributed to reduce insecticide efficacy. An unforeseen precipitation $(15 \mathrm{~mm})$ occurred two hours after the first application of the insecticides. A formulation of imidacloprid specially developed for citrus stem application $(200 \mathrm{~g} / \mathrm{L}$ soluble concentrate) is not recommended for application during rainy days (AGROFIT, 2008). The imidacloprid formulation AL $(100 \mathrm{~g} / \mathrm{L})$ used in this study is also a special formulation for stem application; but there was no rain during two days after the second application and yet the percentage of attacked leaves increased at the second evaluation.

Since thirty percent of the branches attacked has been indicated as an economic threshold level for the guava-psyllid (BARBOSA et al., 2001a), there is an urgent need to conduct a research to try to find an insecticide that provides fast and efficient control of this pest at such infestation level.

From the results of this study we concluded that imidacloprid AL, $100 \mathrm{~g} / \mathrm{L}$ at 5, 10 or $20 \mathrm{~mL}$ applied once onto the guava stem; imidacloprid SC, $200 \mathrm{~g} / \mathrm{L}$ at $0.6 \mathrm{~mL} /$ tree and thiacloprid SC, $480 \mathrm{~g} / \mathrm{L}$ at $0.2 \mathrm{~mL} /$ tree sprayed twice (15 day interval) on the guava foliage provide no satisfactory control of the guava-psyllid population at a high-density level of infestation.

We wish to thank Paulo Rogério Nunes (UENF/ LFIT) and Ederaldo Azeredo da Silva (UENF/LEF) for their technical assistance. Funds for this study was provided by the Fundação Carlos Chagas Filho de Amparo à Pesquisa do Estado do Rio de Janeiro (FAPERJ).

\section{REFERENCES}

AGROFIT. Sistema de Agrotóxicos Fitossanitários.

Accessible at: <http//extranet.agricultura.gov.br/agrofitcons/principal-agrofit-cons>. Access on: 24 June 2008.

BARBOSA, F. R.; FERREIRA, R. G.; KIILL, L. H. P.; SOUZA, E. A.; MOREIRA, W. A.; ALENCAR, J. A.; HAJI, F. N. P. Nível de dano, plantas invasoras hospedeiras, inimigos naturais e controle do psilídeo da goiabeira (Triozoida sp.) no Submédio São Francisco.

Revista Brasileira de Fruticultura, Jabotical, v. 25, n. 3, p. 425-428, 2003.

BARBOSA, F. R.; HAJI, F. N. P.; ALENCAR, J. A.; MOREIRA, W. A.; GONZAGA NETO, L. Psilídeo da goiabeira: monitoramento, nível de ação e controle. Petrolina: CPATSA-Embrapa, 2001a. 8 p. (Circular técnica, 74).

BARBOSA, F. R.; SANTOS, A. P.; HAJI, A. T.; MOREIRA, W. A.; HAJI, F. N. P.; ALENCAR, J. A. Eficiência e seletividade do imidacloprid e lambdacyhalothrin no controle do psilídeo (Triozoida sp.), em goiabeira. Revista Brasileira de Fruticultura, Jaboticabal, v. 21, n. 3, p. 385-387, 1999. 
BARBOSA, F. R.; SOUZA, E. A. de; SIQUEI RA, K. M. M.; MOREIRA, W. A.; ALENCAR, J. A.; HAJI, F. N. P. Eficiência e seletividade de inseticidas no controle do psilídeo (Triozoida sp.), em goiabeira. Pesticidas:

Revista de Ecotoxicologia e Meio Ambiente, Curitiba, v. 11, p. 45-52, 2001 b.

CASTLE, S. J.; BYRNE, F. J.; BI, J. L.; TOSCANO, N. C. Spatial and temporal distribution of imidacloprid and thiamethoxam in citrus and impact on Homalodisca coagulata populations. Pest Management Science, London, v. 61, n. 1, p. 75-84, 2005.

NAKANO, O.; SILVEIRA NETO, S. Contribuição ao estudo de Triozoida sp. Crawf., praga da goiabeira. Ciência e Cultura, Campinas, v. 20, p. 263-264, 1968.

TOMIZAWA, M.; CASIDA, J. E. Neonicotinoid insecticide toxicology: mechanisms of selective action Annual Review of Pharmacology and Toxicology, Palo Alto, v. 45, p. 247-268, 2005. 